\title{
Stakeholder perception of financial performance in corporate reputation formation
}

\author{
Ivan Derun \\ Faculty of Economics, \\ Taras Shevchenko National University of Kyiv, \\ Ukraine \\ derun@knu.ua \\ Hanna Mysaka \\ Faculty of Economics, \\ Taras Shevchenko National University of Kyiv, \\ Ukraine \\ mysaka_g@knu.ua
}

Abstract. Diversity of corporate reputation understanding concepts complicates its comprehensive reflection in financial statements. This paper presents the study results on the influence of stakeholder perception of financial performance on corporate reputation. The goal of this article is to identify the signs of maximizing the value of corporate reputation by analyzing public companies' financial performance. We have determined that company's commercial success and its business model prospects becomes the evidence of the corporate reputation's financial component, which is formed simultaneously under the influence of the stakeholder perception. The analysis results lead us to the conclusion that the corporate reputation's financial component is more sensitive to investors' perception rather than to consumers' perception. This is because analysis of financial statements is an important stage in making investment decisions. Instead, consumer commitment is formed by mostly non-financial factors. In our conclusions, we suggest modernizing the existing accounting approaches to intangible assets that will strengthen the image and corporate reputation, increase company's market capitalization and improve its investment attractiveness.

Keywords: brand, consumer perception, corporate reputation, financial performance, financial statements, intellectual capital, internally generated goodwill, investor perception, market capitalization.

JEL Classification: M41, M31, M21 


\section{INTRODUCTION}

It is simply not possible to give an adequate assessment of any business - especially a successful one beyond the context of its corporate reputation. Reputation covers stakeholders' views about the company, which for a long time conducts its business activity on the basis of professionalism, decency and compliance with the current legislation. At various stages of company's life cycle, the intangible nature of reputation has the opportunity to adopt into specific financial performance of goodwill:

- as a result of a business acquisition: as a payment made by the buyer in anticipation of future economic benefits from the assets that cannot be individually determined, or recognized separately;

- internally generated goodwill: for the companies whose shares are listed at stock exchange - as excess of market capitalization over the market value of net assets (Ivanov et al., 2017).

If the first type of goodwill can be reliably measured as a result of a business transaction, meets the requirements for recognizing the asset and is displayed by the new owner in accordance with the financial reporting standards, the generally accepted method for evaluating the successful company's internally generated goodwill does not exist. Company's ability to generate excess profit is a consequence of the complex interaction of a large number of factors, some of which cannot be valued. For example, personal goodwill is the goodwill of the head of a firm inseparable from his/her personality.

The society informatization processes contribute to the growth in volumes of production and sales of intangible goods, the demand for which is directly dependent on consumer confidence. A brand is created to accelerate the dissemination of information about a company that already has positive reputation. A brand activates the realization of the general potential of the company-owner by creating a stable perception of the product reputation in conjunction with the trademark, as a symbol of the brand in consumer consciousness. The brand value growth automatically increases the goodwill of owner(s). However, without attracting significant external financing, it is impossible to achieve the essential multiplication of investments into a brand and to increase goodwill, so it is necessary to create a positive image of the company in the eyes of potential investors.

Formation of corporate reputation is a long-lasting process and it depends on the effect of company's business activity on the broad spectrum of stakeholders, both external and internal. The stakeholders' perception of the company is based on the analysis of information available to them. Therefore, the issues of ensuring trust between the users of this public data, the maximum level of disclosure become increasingly important. The sources of such information and the methods of its research vary depending on what has caused the stakeholders' interests to company's business activity and the level professional training and experience too.

Consumers and investors are interested in the results of company's business activity and they tend to have their own ideas about it. As the most numerous and influential groups of stakeholders they are guided by different considerations and approaches. However, in our opinion, they all directly (investors) or indirectly (consumers) take into account the information provided by public companies in their financial statements. If analysis of performance indicators is a standard step in the process of making an investment decision, consumers receive their part of information about company's financial position and performance in the form of brand ratings. In the course of rating brands the most influential world agencies use financial data about past and current income and expenses of a brand (Interbrand method) or information concerning the discounting potential revenue that a brand can generate (Brand Finance method). Nowadays, financial statements are the only source of comparable and relatively reliable information on companies' business activities. Therefore, financial reporting items could be used to determine the peculiarities of the impact of corporate reputation perception by different stakeholder groups, which is important for effective goodwill management. 
Our goal is to identify the signs of maximizing the value of corporate reputation by analyzing financial performance of public companies. For this reason, we have differentiated the link between financial performance and corporate reputation's financial component for the two largest groups of stakeholders (investors and consumers).

To achieve our goal we have tested the following two hypotheses. Firstly, we wanted to verify that investors are more sensitive to company's profitability ratios rather than to its innovation level ratios. Secondly, we wanted to test how consumer adherence depends on a company's financial performance.

\section{LITERATURE REVIEW}

During the last 25-30 years the essence of corporate reputation has been the research subject in the field of economics, finance, law, sociology, etc. Expansion and advancing the frontiers in the study process of this phenomenon caused some uncertainty in the use of the terms for the comparative analysis of these researches. In particular, some scholars outline several approaches for reputation definition (economic, strategic, marketing, accounting, organizational, sociological, etc.), which causes the ambiguity of the concepts of identity, image, reputation. (Chun, 2005; Barnet et al., 2006; Cornelissen et al., 2007; Walker, 2010; Clardy, 2012; Feldman et al., 2014). It also leads to a ambiguous understanding of the corporate reputation itself, since it can be considered as an awareness of the stakeholders, an asset and an assessment (Barnet et al., 2006; Lange et al., 2011; Jakab and Happ 2017).

Terminological diversity forms a number of problems related to the origin and the subjects that create the corporate reputation of the company. In particular, different groups of stakeholders can differently perceive and reflect the corporate reputation. (Foroudi et al., 2014; Olmedo-Cifuentes et al., 2014; Pritchard \& Wilson, 2017). So, I. Olmedo-Cifuentes, I. Martinez-Leon and G. Davies investigate the corporate reputation creating through manager perception and employee perception (Olmedo-Cifuentes et al., 2014). M. Pritchard and T. Wilson determine the corporate reputation creation through the prism of consumer perception of the company's products and services (Pritchard \& Wilson, 2017). While A. BlajerGolebiewska and M. Kos research the relationship between corporate reputation and individuals' investment decisions (Blajer-Golebiewska \& Kos, 2016).

This in turn leads to a variety of approaches to measuring the corporate reputation (Black et al., 2000; Chun, 2005; Clardy, 2012; Fombrun et al., 2007; Sarstedt et al., 2013). In particular, A. Clardy identifies five methodological approaches to measuring the corporate reputation, namely: as an asset, as a brand, as an evaluative judgement (for example, ratings of specialized publications) such as personality (identification of a company with a particular product) and as general knowledge (representation of the company based on different advertising or other media, comments of acquaintances and friends, etc.) (Clardy, 2012). Brand ratings, which are developed by specialized mass media, are currently one of the most common sources of professionally formed corporate reputation for the companies (Fombrun, 2007). For instance, the reputation rating of 1,000 companies in the world, released by Fortune magazine, is a key quantitative measure of the corporate reputation, and its results are systematically used in research. Another instrument of corporate reputation measuring can be a brand (Black et al., 2000; Chun, 2005; Clardy, 2012). However, the existence of different methods of calculating the brand imposes restrictions on the application of this approach because of the non-comparability of their results. A further approach to dimensioning corporate reputation may be considered image measures that determine the corporate reputation as one of the endogenous factors that influence the perception of the company. R. Ali, R. Lynch, T. Melewar and Z. Jin carried out a comprehensive meta-analysis of factors that affect the corporate reputation and the implications for different stakeholders (Ali et al., 2015). M. Sarstedt, P. Wilczynski and T. Melewar conducted the analysis of the efficiency of developed corporate reputation measurement techniques. In their 
study, they compared the efficiency of using such techniques as the America's Most Admired Companies Index (AMAC index), the reputation quotient (RQ), customer-based corporate reputation (CBR). The result of its srudy was concluded that the most accurate measure of the company's success is provided by the RQ methodology (Sarstedt et al., 2013).

Separate attention should be paid to identifying the causal relationships between corporate reputation and financial performance (Sabate \& Puente, 2003; Dowling, 2006; Tischer \& Hildebrandt, 2014; Paulík et al., 2015). In particular, J. Sabate and E. Puente systematized the genesis of research and methodology conducted over the past 30 years on the identification and measurement of the relationship between corporate reputation and business performance. According to their findings, well-known specialized publications, such as Fortune, have often adopted indicators such as earnings per share, P/E, ROIC, average yield, Tobin's Q, return on sales, asset turnover, beta, ROA, market value, etc. The relationship between measured corporate reputation and financial and economic performance of a company was determined by methods of regression, correlation and cluster analysis (Sabate \& Puente, 2003).

Professional appraisers use several approaches for valuing assets:

1) Valuation of discounted cash flows based on the comparison of the asset's value with the present value of expected future cash flows from its use;

2) Calculating the value of the relevant asset based on comparing the prices of analog assets on the active market. This is due to the assumption of the correctness of the value of the asset in the market, where there is no data asymmetry, and the market price is balanced by demand and supply;

3) Estimation of the conditional requirements, based on options assessment models that can be used to evaluate of patents, oil stocks, etc. (Damodaran, 2017).

The valuation of the corporate reputation based on financial indicators should be carried out by the method of comparative assessment and needs to use financial statements as a data background.

G. Dowling studied the influence of corporate reputation on financial performance. In particular, he argues that good reputation can improve key financial performance and significantly increase the company's internal value with the help of such drivers as investing to achieve a return in excess of the cost of capital, business growth and risk management (Dowling, 2006). S. Tischer and L. Hildebrandt investigated the impact of the publication of corporate reputation ratings on the company's share capital gain and the acquisition of significant profits (Tischer \& Hildebrandt, 2014).

The research of modern trends in the indication of the corporate reputation index has allowed to conclude that enforce the high level of ethic business standards and a consistent demonstration by the corporation of a socially responsible position are the most significant catalysts of the corporate reputation growth, and their good management helps to increase the company profitability and efficiency (Melo \& Garrido Morgado, 2012; Bilan, 2013; Feldman et al., 2014; Agarwal et al. 2015; Arikan et al., 2016; Dowling, 2016). J. Agarwal, O. Osiyevskyy and P. Feldman asserted that the corporate reputation can be estimated through its individual measurable dimensions, such as vision and leadership, the workplace environment, product quality, social and environmental responsibility, financial indicators, emotional understanding (Agarwal et al., 2015). P. Feldman, R. Bahamonde and I. Velasquez Bellido offered a comprehensive index of the corporate reputation measurement, which includes various indicators of company performance (Feldman et al., 2014).

The study, presented in this paper, differs from previous research. Firstly, we have determined the influence of stakeholder perception of a company financial performance on the corporate reputation financial component. Secondly, we have used a system of financial ratios that reflect the specifics of investors and consumer perception for the quantitative measurement of these effects. This financial performance was calculated according to the data of the financial statements and information on the market capitalization of the companies. 


\section{METHODOLOGY}

The stakeholder perception of a company, which is embodied in goodwill and reflected in other financial parameters of its functioning, is formed under the influence of a number of factors of different origins. Specialists from the Reputation Institute, who have been exploring the corporate reputation for more than 20 years, have identified seven of its components, which in aggregate provide an adequate assessment of any business (Fombrun et al., 2015). In our opinion, it is advisable to combine these components into three groups, depending on their connection with certain aspects of the company's business activity:

1) Personnel: leadership, workplace and governance - characterize the atmosphere in the company's team;

2) Image: Products \& Services, innovation and citizenship - characterize the degree of adaptability of the company to the needs and expectations of consumers;

3) Financial: performance - a set of indicators that are determined based on the data of the financial statements to characterize the commercial success of the company and assess the prospects of its business model.

Internally generated goodwill, as a value of the company's reputation, is the result of the complex interaction of all its components. At the same time, in contrast to the personnel and image components, the corporate reputation financial component due to the cost estimation and standardized methodology for reporting indicators can be compared both in terms of different companies and at the different reporting periods.

Our assumption consists in the fact that, as the different stakeholder perceptions form the corporate reputation, the financial component of corporate reputation should be determined separately for each such group, taking into account the peculiarities of their expectations regarding the future of the companies.

The reputation of a public company is a subject of the most significant impact by consumers of its product and investors - members of the stock exchanges, where its shares are listed. One of the value measures of a public company success is the size of its market capitalization, since the price of shares largely depends on investor expectations of profits that the company can generate in the future and speculative sentiments reflecting the stock exchange participant interest. Shareholders use the ratio of the company market capitalization to its net asset value ( $\mathrm{P} / \mathrm{B}$ ratio), since it gives an idea of what remains of their investments in the company in the event of its immediate liquidation. The ratio of the company market capitalization to its annual total revenue ( $\mathrm{P} /$ Total revenue ratio or $\mathrm{P} /$ Sales ratio), which is also used for the comparative estimation of investment attractiveness of companies, reflects the attitude of consumers towards the company's products and simultaneously characterizes its business activity.

The process of determining market value of a company's net assets is too complex and labor-intensive, and its deviation from the financial statements for public companies is not significant in the most cases. That is why in the framework of this study we calculated the value of the internally generated goodwill according to an approach that was used in practice for simplification of Tobin's ratio calculation, when the recoverable value of assets is replaced by their balance value. Thus, the modification of the calculation of the internally generated goodwill was carried out by changing the market value of the company's net assets on their balance value. So, the internally generated goodwill was calculated as the difference between the company market capitalization and its net asset value.

In our opinion, the internally generated goodwill divided by the indicators of the financial statements, which reflects the most significant value parameters of the investor and consumer perception of the company, will allow to separate and determine the impact on the financial component of the corporate reputation two of the most numerous and influential groups of stakeholders. Due to the same conservative 
approach inherent in accounting, as a result of the use of financial statements, the risk of the corporate reputation revaluation for the characteristics of its financial component was minimized.

Thus, the result of the determination of the financial information impact on a the corporate reputation through its investor perception was the ratio of internally generated goodwill modified value to its net asset value as an indicator of the investor participation in financing the company's business activity. The financial performance impact on the corporate reputation through its consumer perception, was calculated as internally generated goodwill modified value divided with the amount of total revenue as a value expression of the consumer commitment to the product that the company offers.

To test the hypotheses, we have constructed two econometric models that determine the impact investor (1) and consumer (2) perception on the financial component of the corporate reputation, based on panel data:

$$
\begin{gathered}
y_{i t}=\beta_{0}+\beta_{1} x_{1 i t}+\beta_{2} x_{2 i t}+\beta_{3} x_{3 i t}+\varepsilon_{i t}, \\
i \in \underline{1,3}, t \in \underline{2012,2016}
\end{gathered}
$$

Where $y_{i t}-(\mathrm{P}-\mathrm{B}) / \mathrm{B}$ ratio $(\mathrm{P}-$ company market capitalization; $\mathrm{B}$ - company net asset value);

$x_{1 i t}-\mathrm{ROE}$ (Return on Equity);

$x_{2 i t}-\mathrm{R} \& \mathrm{D}$ costs/Operating Expenses ratio;

$x_{3 i t}-$ Return on Intangible Assets (Net Income/(Net Intangible Assets+Goodwill));

$\beta_{0}, \beta_{1}, \beta_{2}, \beta_{3}$ - parameters of the econometric model;

$\varepsilon_{i t}-$ stochastic remnants.

$$
\begin{gathered}
z_{i t}=\alpha_{0}+\alpha_{1} w_{1 i t}+\alpha_{2} w_{2 i t}+\alpha_{3} w_{3 i t}+\varepsilon_{i t}, \\
i \in \underline{1,3}, t \in \underline{2012,2016}
\end{gathered}
$$

Where, $z_{i t}-(\mathrm{P}-\mathrm{B}) /$ Total Revenue ratio;

$w_{1 i t}-$ ROS (Return on Sales);

$w_{2 i t}-$ Operating Income/(Cost of Revenue+Operating Expenses) ratio;

$w_{3 i t}$ - Inventory Turnover;

$a_{0}, a_{1}, a_{2}$ - parameters of the econometric model;

$\varepsilon_{i t}$ - stochastic remnants.

The choice of indicators for including in model 1 was due to their significance in the process of making financial decisions by potential investors. Thus, the $\operatorname{ROE}\left(\chi_{1 i t}\right)$ is a key indicator of the retrospective assessment of the efficiency of the company using its owners' funds. The R\&D costs to-to Operating Expenses ratio $\left(x_{2 i t}\right)$ indicates the company innovation level. The return on intangible assets $\left(x_{3 i t}\right)$ gives an indirect indication of the overall success of the company's innovations (as a book value of intangible assets) and investments made in other companies' capital (as a recognized goodwill at acquisition).

Model 2 included indicators that show how much consumers prefer company's products. In particular, ROS $\left(w_{1 i t}\right)$ and the Operating Incom to-to (Cost of Revenue+Operating Expenses) ratio ( $\left.w_{2 i t}\right)$ reflect success of pricing policy conducted by the company and the ability to effectively manage operating expenses. The inventory turnover $\left(w_{3 i t}\right)$ determines not only the level of the company's business activity as a whole, but also demonstrates its marketing policy efficiency.

The testing of hypotheses was carried out according to the data of 100 public companies for 20122016, which are included in the Brand Finance rating as one of the most common approaches to brand valuation used by leading analytical agencies in the world. The Brand Finance is based on the calculation of 
the sum of discounted potential revenue, which may be produced by the brand, as well as on the estimation of the royalty rate used to calculate the brand value. In addition, all sample units should match the following requirements:

1) Exceeding the market capitalization over the net assets value, as an evidence of internally generated goodwill of a public company;

2) Indicating R\&D costs in Income statement (Statement of profit or loss and other comprehensive income for the period) as a separate item, which is an evidence of the significance of their level as an intensity indicator of the company's search for innovative solutions to support and develop the brand;

3) profit-making during the research periods as a sign of the public company's financial efficiency.

The data of 41 public companies matched to the specified requirements for the selected sample. The financial portals MarketWatch and Uchart were the sources of the financial statements and the company market capitalization.

Therefore, the formed sample consists of three dimensions, which are typical for panel data, namely: signs (independent variables) - financial performance, objects - public companies, time - reporting periods. The use of multi-factor regression with panel data provides leveling of individual heterogeneity of objects (public companies) and allows obtaining more accurate estimates of model parameters.

\section{RESULTS}

Before applying these economic-mathematical models, all dynamical rows of independent variables were investigated for stationary using the Dickey-Fuller test. According to the obtained results, all the dynamic series are stationary, which enables them to be taken into account in the proposed models for assessing the impact of investor and consumer perception on the corporate reputation financial component. This gives grounds for calculation the linear multiple regression using the data of the financial statements of 41 public companies, the parameters of which are presented in table 1, table 2 and table 3.

Table 1

Model parameter estimation for measuring the influence of investor perception

\begin{tabular}{|c|c|c|c|c|}
\hline Variable & Coefficient & Std. Error & t-Statistic & Prob. \\
\hline$x_{1 i t}$ & 19.17759 & 0.416050 & 46.09441 & 0.0000 \\
\hline$x_{2 i t}$ & -6.777664 & 3.154028 & -2.148891 & 0.0338 \\
\hline$x_{3 i t}$ & -0.932139 & 0.296409 & -3.144774 & 0.0021 \\
\hline$\varepsilon_{i t}$ & 3.670491 & 2.038288 & 1.800771 & 0.0744 \\
\hline R-squared $=0.957 ;$ F-statistic $=66.800 ;$ Prob.(F-statistic) $=0.000$ & \\
\hline
\end{tabular}

Source: calculated by authors.

The obtained results give grounds to assert that model 1 is adequate to the Fisher criterion, and all parameters are significant, since their Prob.(F-statistic) $<0.05$. The density of the link between the model components is $95.7 \%$, which indicates the significance of the influence of investor perception of the financial performance on the corporate reputation financial component (see table no. 1). Further analysis of the parameters of the model 1 allows us to draw the following conclusions and assumptions:

1) The investor's attitude the corporate reputation financial component of the company's undergoes the most significant changes under the direct relationship of the ROE $\left(x_{1 i t}\right)$. It is testimony to their primary interest in how much profit the company provided to its owners in the past;

2) The company's innovation indicators used in the model (the R\&D costs to-to Operating Expenses ratio $\left(x_{2 i t}\right)$ and the Return on Intangible Assets $\left(\mathrm{x}_{3 i t}\right)$ showed inverse relationship with the corporate reputation financial component. It can be interpreted as a manifestation of investor conservatism, since the 
high level of costs of innovation does not only guarantee their commercial success in the future, but generally implies a decline in a company current profit-making.

Table 2

Model parameter estimation for measuring the influence of investor perception

\begin{tabular}{|c|c|c|c|c|}
\hline Variable & Coefficient & Std. Error & t-Statistic & Prob. \\
\hline$w_{1 i t}$ & 7.278661 & 6.144423 & 1.184596 & 0.2390 \\
\hline$w_{2 i t}$ & $3.83 \mathrm{E}-05$ & $6.26 \mathrm{E}-05$ & 0.610995 & 0.5426 \\
\hline$w_{3 i t}$ & 0.000371 & $7.02 \mathrm{E}-05$ & 5.292332 & 0.0000 \\
\hline$\varepsilon_{i t}$ & 0.737336 & 0.701866 & 1.050537 & 0.2960 \\
\hline R-squared $=0.667 ;$ F-statistic $=5.565 ;$ Prob.(F-statistic) $=0.000$ & \\
\hline
\end{tabular}

Source: calculated by authors.

Model 2 is also adequate to the Fisher criterion, but the two variables $w_{1 i t}$ and $w_{2 i t}$ are not significant as they have Prob.(F-statistic) $<0.05$ (see table no. 2). Therefore, in order to adjure the model, insignificant factors were excluded. The results of the parameters of the adjusted model 2 are given in table 3.

Table 3

Adjusted model parameter estimation for measuring the influence of investor perception

\begin{tabular}{|c|c|c|c|c|}
\hline Variable & Coefficient & Std. Error & t-Statistic & Prob. \\
\hline$w_{3 i t}$ & 0.000355 & $5.54 \mathrm{E}-05$ & 6.402918 & 0.0000 \\
\hline$\varepsilon_{i t}$ & 1.652710 & 0.122867 & 13.45123 & 0.0000 \\
\hline R-squared $=0.644 ;$ F-statistic=5.547; Prob.(F-statistic) $=0.000$ \\
\hline
\end{tabular}

Source: calculated by authors.

As a result of the adjustment, model 2 retained the Fisher criterion adequacy; the only remaining variable $w_{3 i t}$ is significant, while the exception of non-essential factors led to a decline in the density of the link between its components from $66.7 \%$ to $64.4 \%$. This can be explained by the fact that financial performance affects the consumers only in directly, but their perception of company products is significantly reflected on its business performance. In turn, companies with a positive corporate reputation have a high level of business activity, which is one of the factors of business success.

The irrational consumer desire to own branded products leads to inelastic demand for them. Therefore, the $\operatorname{ROS}\left(w_{1 i t}\right)$ and the Operating Income to-to (Cost of Revenue+Operating Expenses) ratio ( $\left.w_{2 i t}\right)$ demonstrate insignificant influence of consumer perception on the corporate reputation financial component. This weakens the link between the company financial performance and the corporate reputation financial component. While positive attitude of consumers plays a significant role in increasing business activity, it is entirely logical to assume that successful financial management will help a company to maximize both the profit-making and the market capitalization in the future. In general, both models results indicate that the internally generated goodwill, as a value of corporate reputation, is sensitive to changes in the financial statement items. The internally generated goodwill is inseparable from the company in contrast to other intangible assets (in particular, brands, licenses, trademarks, patents, etc.). Therefore, it is not a subject to accounting, and cannot be reflected in a Statement of financial position (balance sheet) at the end of the period, because of non-compliance with the assets recognition criteria and the impossibility of reliable assessment.

Intangible elements (the corporate reputation, technology, qualifications and employee motivation, corporate culture, customer base, etc.) mainly provide value added creating, competitive market advantages and increasing the company market capitalization in modern conditions the conduct of business. That is 
why intellectual capital as the system of these elements is a full-fledged production factor along with physical capital. At the same time, the heterogeneity and specificity of intellectual capital make it impossible to apply a single measure to its elements, and the intangible nature, unlike physical capital, requires not only value measurement. This feature of intellectual capital provides its focus on the company furthe development, while financial capital is the result of its business activities in past periods. Therefore, along with traditional financial statement data, stakeholders increasingly need information about the non-monetary valuation of intellectual capital, based on which one can get an idea of the strategy of company development, its competitiveness and investment attractiveness.

Intellectual capital creating, developing and supporting need significant investments, just like the financing of physical capital occurs, despite intellectual capital intangible nature and the fact that it belongs to a company partially. However, the law of conservation of values used in the theory of corporate finance to evaluate the company physical capital, in terms of intellectual capital valuation can only be used to state that each element has a certain value. This follows from the concept of intellectual capital, according to which the loss of one of its elements leads to the impairment of its entire intellectual capital and the company itself. In this context company can achieve an essential increase in the its physical capital efficiency due to the individual competencies of staff and corporate culture as elements of intellectual capital. Properties like this have allowed some scientists to conclude that the value of intellectual capital elements need not to add, but to multiply in the process of determining its integral value (Edvinsson \& Malone, 1997).

But traditional accounting methodology is based on the presumption of additivity of all variables, which is typical for physical capital as a long time dominant production factor. Therefore existing accounting methods cannot adequately reflect the synergetic effect that results from the complex interaction of intellectual capital elements. Although some elements of intellectual capital match asset recognition criteria and are disclosed in the financial statements, accounting methods do not always correctly reveal their nature that lead to a distorted reflection of the mechanism of its effect on the company financial position or performance. For example, advertising and staff training costs are recognized as expenses and, therefore, underestimate reporting period profit. However, economic effect of their implementation occurs in the next periods in the form of increased productivity of more qualified personnel and an increase in the volume sales as a result of conscious consumer perception of the content of promotional activities. The capitalization of these and other similar costs, with their subsequent recognition as long-term assets, will contribute to:

1) More accurate profit and loss calculation as a result of distributing of these costs between periods according to the matching principle due to cause-and-effect relationship between income and the expenses;

2) Expanded recognition of the internally generated goodwill and detailed disclouse of its individual elements in the company financial statements.

R\&D costs could be capitalized only partially, just in case of successful results of their carrying out. They are transformed into such intangible assets as patents, know-how, etc., on the basis of the primary documents at their actual cost. Therefore, de facto their influence on the fair evaluation of the internally generated goodwill is rather insignificant. In other cases, the recognition of individual elements of intellectual capital as intangible assets, with subsequent regular decrease in their value as a result of depreciation contradicts with the real consequences of their use. In particular, successful trademarks or brands over time could increase their real value, first and foremost, due to consumer commitment gained during previous periods. Those elements of intellectual capital, which have only non-monetary estimation, are not recognized in accounting and are not disclosed at the financial statements at all.

In our opinion, companies that do not draw up Intellectual Capital Accounts, should be increasing the reliability and informativeness of their financial statements about the corporate reputation as an important element of intellectual capital. They could include information about customer service and marketing 
strategy, innovations and product development, corporate culture, qualifications and more at the notes to the financial statements. These important elements of intellectual capital have both financial and nonfinancial characteristics and should be represented in the context of the current state, results and prospects for the development. In this case, financial aspects can be disclosed in two directions:

1) Relative - the illustrating the benefits that the company gained from the intellectual capital use (increasing Total revenue and Net income as a result of developing new products) through a system of profitability and business efficiency ratios;

2) Absolute - the display of an alternative assessment of intangible assets at the fair value; disclosure of R\&D costs, advertising, training of staff.

This will impact at increasing the company investment attractiveness and improve its position in the brand ratings, as the basic indicators of investor and consumer perception of the company.

\section{CONCLUSIONS}

The impact of company financial performance on its corporate reputation varies greatly from the interests of different stakeholder groups, because they use this information in the decision-making process. In particular, the influence of investor perception of the financial performance on the corporate reputation financial component is much more substantive than consumer one, since the analysis of these data is one of the investment decision-making common steps. This study results show that investors are more interested in the prospects of return on their investment than on the business innovation that company conduct. Recovering from aftershock of the global financial crisis, stock exchange market participants have increasingly shown conservative investing and are cautious in financing new technologies and developments issuers, perceiving this as a factor in increasing risk and reducing the profitability of the business.

Instead, the impact of consumer perception of the financial performance on the corporate reputation financial component as a whole is not sufficiently substantial. Obviously, consumer commitment to the company products is formed, mainly, taking into account non-financial factors (product quality, prestige product, product innovation and exclusivity). As a result, it provides such companies with high level of business activity indicators, therefore the corporate reputation financial component through the consumer perception revealed sensitivity only to the change in inventory turnover.

The limited possibilities of traditional accounting methodology reduce the adequacy of information about the internally generated goodwill as a value of the corporate reputation on the financial statements. To increase the level of awareness financial statement users companies should supplement the notes to the financial statements with data about the market valuation of the corporate reputation elements, in order to stakeholders can evaluate the intangible advantages and risks of the company.

In the future, there is an urgent need to revise and modernize the existing accounting approaches for the certain elements of the corporate reputation, in particular, to their recognition and assessment according to the economic essence of their using mechanism. Moreover, the new accounting methods should be developed that would allow the maximum coverage and correctly disclose in the financial statements the intellectual capital elements of the company. This will enhance the status of the financial statements as a reliable source of diverse information, will strengthen the company image and its corporate reputation, increase the company market capitalization and improve its investment attractiveness. 


\section{REFERENCES}

Agarwal, J., Osiyevskyy, O. \& Feldman, P. M. (2015). Corporate reputation measurement: Alternative factor structures, nomological validity, and organizational outcomes. Journal of Business Ethics, 130(2), 485-506. doi: https://dx.doi.org/10.1007/s10551-014-2232-6

Ali, R., Lynch, R., Melewar, T. C. \& Jin, Z. (2015). The moderating influences on the relationship of corporate reputation with its antecedents and consequences: A meta-analytic review. Journal of Business Research, 68(5), 1105-1117. doi: https://dx.doi.org/10.1016/j.jbusres.2014.10.013

Arikan, E., Kantur, D., Maden, C. \& Telci, E. E. (2016). Investigating the mediating role of corporate reputation on the relationship between corporate social responsibility and multiple stakeholder outcomes. Quality \& Quantity, 50(1), 129-149. doi: https://dx.doi.org/10.1007/s11135-014-0141-5

Barnett, M. L., Jermier, J. M. \& Lafferty, B. A. (2006). Corporate reputation: The definitional landscape. Corporate reputation review, 9(1), 26-38. doi: https://dx.doi.org/10.1057/palgrave.crr.1550012

Bilan, Y. (2013). Sustainable development of a company: Building of new level relationship with the consumers of XXI century. Amfiteatru Economic, 15(7), 687-701.

Black, E. L., Carnes, T. A. \& Richardson, V. J. (2000). The market valuation of corporate reputation. Corporate Reputation Review, 3(1), 31-42. doi: https://dx.doi.org/10.1057/palgrave.crr.1540097

Blajer-Golebiewska, A., \& Kos, M. (2016). Investors are more sensitive to information about financial rather than ethical reputation of a company: evidence from an experimental study. Economics \& Sociology, 9(1), 11, 11-22. doi: https://dx.doi.org/10.14254/2071-789X.2016/9-1/1

Chun, R. (2005). Corporate reputation: Meaning and measurement. International Journal of Management Reviews, 7(2), 91 109. doi: https://dx.doi.org/10.1111/j.1468-2370.2005.00109

Cornelissen, J. P., Haslam, S. A. \& Balmer, J. M. (2007). Social identity, organizational identity and corporate identity: Towards an integrated understanding of processes, patternings and products. British Journal of Management, 18, 1-16. doi: https://dx.doi.org/10.1111/j.1467-8551.2007.00522.x

Clardy, A. (2012). Organizational reputation: Issues in conceptualization and measurement. Corporate Reputation Review, 15(4), 285-303. doi: https://dx.doi.org/10.1057/crr.2012.17

Damodaran, A. (2017). Investment valuation: Tools and techniques for determining the value of any asset. Moscow: Alpina Publisher. (in Russian).

Dowling, G. (2006). How good corporate reputations create corporate value. Corporate Reputation Review, 9(2), 134-143. doi: https://dx.doi.org/10.1057/palgrave.crr.1550017

Dowling, G. (2016). Defining and measuring corporate social reputations. Annals in Social Responsibility, 2(1), 18-28. doi: https://dx.doi.org/10.1108/ASR-08-2016-0008

Edvinsson, L. \& Malone, M.S. (1997). Intellectual capital: realizing your company's true value by finding its hidden brainpower. HarperCollins Publishers, Inc., New York.

Feldman, P. M., Bahamonde, R. A. \& Velasquez Bellido, I. (2014). A new approach for measuring corporate reputation. Revista de Administração de Empresas, 54(1), 53-66. doi: http://doi.org/10.1590/S0034-759020140102

Fombrun, C. J. (2007). List of lists: A compilation of international corporate reputation ratings. Corporate Reputation Review, 10(2), 144-153. doi: https://dx.doi.org/10.1057/palgrave.crr.1550047

Fombrun, C.J., Ponzi, L.J. \& Newburry W. (2015). Stakeholder tracking and analysis: the RepTrak® system for measuring corporate reputation. Corporate Reputation Review, 18, 3-24. doi: https://dx.doi.org/10.1057/palgrave.crr.2014.21

Foroudi, P., Melewar, T. C. \& Gupta, S. (2014). Linking corporate logo, corporate image, and reputation: An examination of consumer perceptions in the financial setting. Journal of Business Research, 67 (11), 2269-2281. doi: https://dx.doi.org/10.1016/i.jbusres.2014.06.015

Jakab, P., \& Happ, É. (2017), Impact Assessment between the City and the Company Reputation. Economics \& Sociology, 10(1), 279-289.

Ivanov, A. E., Sokolova, N. A., Generalova, N. V. et al. (2017). Goodwill: Synergistic essence, evaluation, accounting, analysis. Moscow: RIOR, INFRA-M. doi: http://doi.org/10.12737/6031 (in Russian).

Lange, D., Lee, P. M. \& Dai, Y. (2011). Organizational reputation: A review. Journal of Management, 37(1), 153-184. doi: https://dx.doi.org/10.1177/0149206310390963

Melo, T. \& Garrido Morgado, A. (2012). Corporate reputation: A combination of social responsibility and industry. Corporate Social Responsibility and Environmental Management, 19(1), 11-31. doi: http://doi.org/10.1002/csr.260 
Olmedo-Cifuentes, I., Martínez-Leon, I. M. \& Davies, G. (2014). Managing internal stakeholders' views of corporate reputation. Service Business, 8(1), 83-111. doi: https://dx.doi.org/10.1007/s11628-013-0188-8

Paulík, J., Kombo, F., \& Ključnikov, A. (2015). CSR as a driver of satisfaction and loyalty in commercial banks in the Czech Republic. Journal of International Studies, 8(3), 112-127.

Pritchard, M. \& Wilson, T. (2017). Building corporate reputation through consumer responses to green new products. Journal of Brand Management, 1-15. doi: https://dx.doi.org/10.1057/s41262-017-0071-3

Sabate, J. M. \& Puente, E. (2003). Empirical analysis of the relationship between corporate reputation and financial performance: A survey of the literature. Corporate Reputation Review, 6(2), 161-177. doi: https://dx.doi.org/10.1057/palgrave.crr.1540197

Sarstedt, M., Wilczynski, P. \& Melewar, T. C. (2013). Measuring reputation in global markets - A comparison of reputation measures' convergent and criterion validities. Journal of World Business, 48(3), 329-339. doi: https://dx.doi.org/10.1016/j.jwb.2012.07.017

Tischer, S. \& Hildebrandt, L. (2014). Linking corporate reputation and shareholder value using the publication of reputation rankings. Journal of Business Research, 67(5), 1007-1017. doi: https://dx.doi.org/10.1016/j.jbusres.2013.08.007

Walker, K. (2010). A systematic review of the corporate reputation literature: Definition, measurement, and theory. Corporate reputation review, 12(4), 357-387. doi: https://dx.doi.org/10.1057/crr.2009.26 